\title{
A televised social problem construction? Pushing back against the invisibility of the male rape victim in American Crime
}

\author{
Dimitris Akrivos \\ Canterbury Christ Church University
}

\section{From reality to representation and back: the rise of 'socially aware' television}

From the news coverage of physical-world events like O.J. Simpson's or Oscar Pistorius' trials and their TV dramatisation to concerns over jurors relying heavily on scientific evidence due to an alleged 'CSI effect' (Mopas, 2007), the boundaries between social reality and its televised counterpart become increasingly fluid. Manning (1998) describes a televised world of 'media loops' whereby images are constantly recycled and reproduced in new contexts. Similarly, Ferrell $(1999$, p. 397) refers to a process through which images nowadays 'bounce endlessly one off the other' creating an 'infinite hall of [mediated] mirrors'. This process goes beyond Baudrillard's (2001) idea of an artificial hyper-reality where people escape from the 'desert of the real'. What Manning (1998) and Ferrell (1999) ultimately suggest is that contemporary reality (including the reality of crime, violence and criminal justice) is inextricably intertwined with its representation and it is therefore imperative that criminological research takes this relationship into consideration.

As far as TV content is concerned, academic scholarship has mainly focused on the study of news discourse, whilst TV fiction has been regarded primarily as a site of pleasure and entertainment (Henderson, 2007). The escapist function served by television (Kubey and Csikszentmihalyi, 1990) and the disproportionate emphasis often placed in fictional narratives on individual pathologies (instead of deeper social forces) for entertainment purposes (Best, 2008) should not be overlooked, but neither should the potential of such narratives to inform and even provide a kind of educating entertainment (the so-called 'edutainment') (Klein, 2011). 
Viewers do not necessarily watch TV with a view to temporarily 'running away' from their mundane everyday problems, but often seek answers to them in the stories they are presented with (Bednarek, 2010). In fact, TV drama formats provide an 'open' space which allows for a more in-depth exploration of controversial issues than the 'closed', strictly factual formats of news media (Schlesinger, Murdock and Elliot, 1983). From the portrayal of the post-9/11 'war on terror' in internationally popular American TV shows like 24 and Homeland to those of youth suicide in 13 Reasons Why, racism within the criminal justice system in The Night Of and violence against women in The Handmaid's Tale, $21^{\text {st }}$-century fictional TV is rife with intricate narratives which do not just entertain, but reflect and allow viewers to make sense of real-life anxieties (Bednarek, 2010; Klein, 2011).

It is precisely this rise of a 'socially aware' TV (Birnbaum and Holloway, 2017) and its ideological function in either encouraging or challenging dominant understandings of the social issues portrayed (Bednarek, 2010) that this chapter focuses on. Within a social constructionist paradigm, the study examines how fictional TV can contribute to the process of social problem construction, that is, how fictional TV portrayals of particular social issues can help elevate these to 'social problems', providing viewers with the language, symbols and images necessary to identify them as such. Adopting a case study design, this project looks at what is still considered to be a rather under-researched and under-represented in fictional TV topic, that is, male rape (Cohen, 2014) and particularly how this is portrayed in the second season of ABC's American Crime.

Cohen's (2014) study on male rape highlighted an important gap in the relevant academic literature: studies on rape in news and fictional media tend to pay little attention to male rape, whilst studies on male rape pay little attention to the media. This study, focusing on the depiction of male rape in the fictional world of American Crime, constitutes a response to the need for further research on media representations of male rape. This is not to suggest that its 
findings are indicative of all representations of male rape in contemporary fictional TV. As a case study offering a qualitative content analysis of American Crime, this project is not concerned with generalisability (Creswell, 2007), yet it allows an in-depth exploration of the discourse around male rape and sexual violence in this particular TV product, thereby making an important contribution to the study of this rather neglected in academic research issue. The study uses the case of American Crime to examine the ideological role of such popular cultural texts in reproducing or subverting dominant views on male rape (for instance, that 'men cannot get raped' or that 'male rape is a homosexual issue'; Javaid, 2015). In doing so, it provides an insight into the cultural dynamics of the claims-making around male rape and relevant issues including consent, sexuality, the victim-perpetrator overlap and vigilante justice. Building on the view of popular culture as a conduit through which social problems are defined, debated or even resolved (Maratea \& Monahan, 2016), this study ultimately argues that such 'socially aware' TV shows can play a crucial role in the demarginalisation of the male victim of sexual violence. Before discussing this argument further, it is important to first look more closely at the constructionist underpinnings of the research.

\section{A televised social problems construction?}

From a constructionist perspective, there is no objective reality but we can only make sense of the world through language (Burr, 2015). In that sense, there are no given social problems, but a condition can acquire 'social problem' status when collectively defined as such (Blumer, 1971; Best, 2008). Social problems are therefore products of claims-making activities 'asserting the need for eradicating, ameliorating, or otherwise changing some condition'. (Spector and Kitsuse, 1987, p. 75-76) 
In their attempt to convince the public about the validity of their claims, those participating in the social problems construction process - from politicians and experts to activists, journalists and celebrities - tend to frame, that is, to typify the condition they wish to have identified as a problem. This framing is three-fold and involves (a) identifying the nature of the alleged problem (grounds); (b) explaining why action needs to be taken (warrants); (c) specifying what needs to be done to resolve it (conclusions) (Best, 1990). Claims-makers often find it easier to achieve legitimacy for their claims by framing the condition as a neglected aspect of an established problem the public is already familiar with (e.g. expanding the domain of child abuse to include smoking around children or circumcision; Best, 2008).

The influence of fictional media content on our perception of the world (including our views on which social conditions, out of the plethora of those competing for our attention on an everyday basis, are 'problems') is, as discussed earlier, no less significant than that of its factual counterpart (Schlesinger, Murdock and Elliot, 1983). For instance, audience studies like those by Kitzinger (1999) and Henderson (2007) have stressed that positive portrayals of sexual abuse in fictional TV narratives (e.g. those challenging the victim's self-blame) can be beneficial for viewers who have been victims of sexual abuse themselves, enabling them to overcome their trauma or even providing them with the language needed to make sense of what happened to them and how they should deal with it. Rowan Miller (2017), the former director of Somerset and Avon Rape and Sexual Abuse Support (SARSAS) in England, makes a similar point in The Guardian: she states that the heightened visibility and accurate portrayal of sexual violence in fictional storylines (like those of Broadchurch and Apple Tree Yard) along with the extensive news coverage of the crimes of celebrities like Rolf Harris and Jimmy Savile have contributed greatly to the dispelling of relevant stereotypes and led to an increase of $284 \%$ in the demand for SARSAS's services since 2013. 
Popular culture, especially fictional TV as one of its most essential components, plays a key part in the social problems process not just because it contributes to the construction of social problems but also because it can serve as a means of pushback, challenging dominant perceptions of constructed social problems and promoting alternative definitions of them (Maratea and Monahan, 2016). For example, former US Vice President Joe Biden argued in a 2012 interview that NBC's Will \& Grace had helped to challenge - or pushback - against the stereotypical popular cultural portrayal of gay characters as flamboyantly effeminate 'others' (NBC News, 2012). Nevertheless, this view of Will \& Grace as a form of pushback against the status quo - particularly, the hegemony ${ }^{1}$ of heteronormativity, which establishes and reproduces a clear masculinity/femininity binary (Butler, 2004; Ludwig, 2011) - is debatable. Walters (2001) and Mitchell (2005) both regard Will \& Grace as a site of 'incorporation' (Williams, 1977), i.e. a programme which appears to be subverting hegemonic social relations of power but in actual fact comes to reproduce heteronormative, sexist and racist ideologies, thereby containing transformative social change.

\section{A symbolic annihilation of male rape victims?}

Feminist research has been largely successful in framing sexual victimisation as a 'women's issue', thereby not paying as much attention to male victims (Javaid, 2016). On a representational level, Tuchman (1978) first talked about the symbolic annihilation of women forty years ago, highlighting their trivialisation, condemnation and omission by the mass media. Whilst progress has clearly been made on that front since (with TV shows like Buffy, Scandal, The Good Wife, Jessica Jones etc. featuring several empowered female characters), the same cannot be argued for male rape victims who still appear to be experiencing a similar symbolic annihilation as their victimisation is often 'overlooked, dismissed, or ignored' 
(Ratner et al., 2003, p. 73) not just in mediated but even in academic discourse (Cohen, 2014). In fact, the three aspects of symbolic annihilation identified by Tuchman (1978) seem to largely echo common male rape myths that men cannot be raped (omission); that men are generally not affected by rape or that this only happens to a minority of people (gay men or prisoners) (trivialisation); that 'real' men are able to defend themselves against their rapists or that gay/bisexual men deserve to be raped since they are deviant and immoral (condemnation) (Abdullah-Khan, 2008; Javaid, 2015).

Since men appear to be victims of gender role expectations (namely, of the desire for dominance and control inherent in hegemonic masculinity) just like women, several studies (Stanko, 1990; Hooks, 2000; Cohen, 2014) have suggested that male-on-male rape could also be regarded as a feminist issue. However, from a constructionist point of view, despite their apparently common grounds, male victimisation is often not considered to be as alarming and worthy of public attention as female one, the two conditions even being in competition with each other in the relevant social problems process. Feminist writers like Gillespie (1996), for example, suggest that, due to the limited resources available for rape support services and the allegedly small number of male rape victims, priority should be given to female support provision. Pitfield (2013) and Cohen (2014) refer to cases of male victims who sought help from rape crisis centres in the UK but were turned away, while Donnelly and Kenyon (1996) argue that the lack or inefficiency of services provision available leaves male rape victims isolated and reluctant to report the offence. By constructing rape and sexual violence as a gendered problem involving female victims and male offenders, feminism has marginalised male victims to the point of rendering them almost invisible (Graham, 2006). This invisibility was until not so long ago reflected in the gendered language of legal definitions of rape providing that 'vaginal intercourse' or 'penile penetration' was required for the offence to be committed. For instance, it was only in 2003 in the UK and in 2012 in the USA that gender- 
neutral definitions of rape were adopted (Abdullah-Khan, 2008; US Department of Justice, 2012).

Despite the progress made through the modernisation of the language of the law, on a societal level the dominant heteronormative frame within which rape is made sense of still constructs the penetration of the normally 'impenetrable' male body as more 'disgusting' and 'unnatural' than that of the female body (Butler, 1993; Javaid, 2015). The act of rape therefore culturally 'feminises' the raped man, leaving him vulnerable to a 'fag discourse' which often makes him reluctant to report the crime or, if he decides to do so, taints his experience of the criminal justice system (Rumney, 2009; Javaid, 2016, 2017). As pointed out by Pascoe (2011) in relation to teenage boys, exchanging sexualised insults - including repudiating the 'fag' label and hurling it at others - constitutes an essential part of the daily interaction among high school male students, namely one which enables them to construct their masculine identities and which can at times have serious, even deadly, consequences. As the second season of American Crime focuses on the alleged sexual victimisation of a high school male student, the influence of this fag discourse on framing the issue of male rape is of key importance to the subsequent analysis.

\section{Methodology}

American Crime was a critically acclaimed anthology crime drama TV show, which was created by John Ridley and aired on ABC from March 2015 to April 2017. Its second season, which received several Primetime Emmy Award and Golden Globe nominations but attracted a moderate viewership of 6,03 million (Lowry, 2016; de Moraes, 2016), dealt with the aftermath of the allegations made by a financial-aid male student (Taylor Blaine) in an affluent 
private high school that one of the basketball team's co-captains (Eric Tanner) drugged and raped him at a school party and then posted lurid photographs of him on social media.

The show and this particular season were purposely selected as a case study due to its subject matter. Due to its firm focus on male rape throughout its 10-episode storyline and its contemporary setting, it was felt that American Crime was more suitable to offer an insight into the media portrayal of male rape in today's Western societies than TV shows which either dealt with the issue in individual episodes [like the ones analysed by Cohen (2014)] or featured multi-episode male rape story arcs but belonged to a different genre (for example, timetravelling drama Outlander). Moreover, American Crime's high school setting provides an additional layer of interest to the analysis. It allows a broader dialogue on the cultural value of such fictional portrayals of male victimisation in the wake of growing (and largely femalecentred) efforts to tackle sexual violence among student populations in US and UK schools, colleges and universities (Napolitano, 2015; Fenton et al., 2016; Franklin, Brady and Jurek, 2017) and in the backdrop of the \#MeToo movement against sexual harassment (Zacharek, Dockterman and Sweetland Edwards, 2018). The relevance of the current study to these topical issues will be considered in more detail in the 'Discussion' section.

The 10 episodes of American Crime's second season (as well as the documentary Inside American Crime Season 2) were accessed through the official ABC streaming service ${ }^{2}$. The method used for the analysis of the collected data was qualitative content analysis, particularly, Altheide and Schneider's (2013, p. 26) ethnographic content analysis (ECA) model which ensured a robust exploratory procedure. ECA refers to an integrated method of locating, retrieving and analysing documents - including televisual texts - for their relevance, importance and meaning. The ECA model stresses the investigator's active engagement in their document-based research, which thus becomes a form of ethnography. Contrary to quantitative content analysis which focuses on the mere numerical relationships between variables, ECA 
considers the content of the studied document within a broader cultural context and involves a search for underlying meanings, patterns and nuances. It is based on a 'constant discovery and constant comparison' of emergent themes (Altheide and Schneider, 2013, p. 26), thereby allowing the researcher to continuously interact with and reflexively analyse the selected texts.

The conception of the qualitative media analyst as an ethnographer is consistent with Kress and van Leeuwen's (2006) view of image readers - including TV audiences and the TV researcher - as 'interactional participants' who eavesdrop on and interpret the acts of the 'represented participants', i.e. the depicted characters. When the text under study is, as in this case, a TV show, it is important that its analysis is not limited to what is spoken, but that attention is also paid to the multi-modality of the text, i.e. the way it combines language, image and sound into a coherent whole (Mason, 2006; Bednarek, 2010). This is not to say that the subsequent analysis undertakes a fine-grain investigation of shot and frame sequence, but that the influence of particular audio and visual elements on the constructed meaning (that is, on the framing of male rape in American Crime) is also taken into consideration to the extent that this falls within the scope of the study. Finally, in order to ensure a tight research focus on male sexual victimisation, secondary story arcs which dealt with issues of public school funding and reverse or intra-racial racism were excluded from the analysis, as they were not relevant to the main storyline of Taylor Blaine's alleged rape.

\section{Analysis}

\section{Victim blaming and 'female rape'domain expansion}

From the opening scene of the first episode, American Crime makes clear to the viewer what its subject matter is: 'I want to report a rape,' states a distraught female voice to the 911 operator enquiring about her emergency. We - i.e. the viewers as interactional participants (Kress and 
van Leeuwen, 2006) - can hear but not see these two characters. Instead, we are being presented only with a transcription of the spoken words against a black background as if we are reading the actual 911 transcript. Apart from its dramatic function, this editing technique offers right from the start a glimpse of the relevant claims-making process which we then see unravelling in this and the other episodes of the season. Similarly, the ensuing scene showing Leyland highschool basketball team's training session not only provides the setting of the story and introduces the key 'players', but also subtly points to the focus of the show on competition and the tensions of physical contact. As the events of the first episode unfold, viewers are able to put the opening scene into perspective, as it is also the scene that closes the episode. The only difference is that in the closing scene we can clearly see who the voice reporting the rape belongs to: Taylor Blaine's mother, Anne, who, after Leyland's principal (Leslie Graham) dismisses her claims about her son getting raped, decides to report the incident to the police.

As the narrative develops, it is mainly Taylor's rather than his alleged rapist's actions that come under scrutiny. His 'rape victim' status is often challenged and Taylor is largely regarded as being primarily to blame for what happened to him. When indecent pictures of him from the basketball team captain's party start being circulated among students on social media, the school suspends Taylor for violating its code of conduct. 'There are pictures of your son engaged in lewd behaviour. What he was doing, he was doing in public,' says principal Graham to Taylor's mother, who criticises the unfairness of her son's suspension. 'What he was doing? You mean what was done to him! [...] My son was raped!' Anne Blaine exclaims in protest (Episode One). The shift from active to passive voice in this exchange (he was doing/was done to him) is indicative of the emphasis placed on Taylor's responsibility and his construction as a disorderly student who deserves to be disciplined (in order to learn how to, as principal Graham puts it, 'make better choices') rather than a victim in need of support. 
Moreover, Taylor's low socio-economic background (he is a financial-aid student and therefore an outsider in an elite private high-school like Leyland) plays a key part in the way his claims are made sense of. From the very beginning, his classmates posting and commenting on Taylor's photographs online refer to him as 'white trash' (Episode One) and, as such, he is seen as unreliable and prone to lying. Taylor's perceived status as unreliable and, by extension, blameworthy is consolidated when the police investigation reveals he had exchanged messages about his aggressive sexual fantasies with the accused (Eric) prior to the party. Despite his protests that Eric spiked his drink, thereby depriving him of any chance to consent to sex, the said explicit messages are viewed by the police, the school and, to an extent, even Taylor's mother as 'a blueprint for a rough encounter' (Episode Four). In that way, the initial rape allegation is relegated to a situation involving (in the words of a school board member) 'a couple of gay boys off at a basketball party' (Episode Four). Even a gay friend of Taylor's at the public school he transfers to after the incident refuses to take his claims seriously. 'The only thing that happened to you is you had a 3 A.M. hookup,' he tells him. 'But nothing happened at that party you didn't want to happen' (Episode Six).

Most importantly, and in accordance with the male rape myths discussed earlier (Javaid, 2015), Taylor's construction as someone who falsely accuses a male classmate of rape strips him not only of his 'victim' but also of his 'male' status, ultimately feminising (even dehumanising) him through the use of a 'bitch' discourse. The latter, which is a variation of Pascoe's (2011) 'fag discourse', allows Leyland's male students to reaffirm their masculine identities by challenging Taylor's. What Kevin (the son of the rich LaCroix family who hosted the party where Taylor was allegedly raped) says to his teammates after the first basketball game since the incident is indicative of this 'bitch' discourse:

He [Taylor] came in there [to the party] like some bitch trying to get turned out. Look, my mom told me, 'bitches always trying to play you, always.' [...] And that dude is a straight bitch. He outed Eric, put my name out there...Bitches, man. And you know what the messed-up part is? It doesn't 
matter how crazy they are, you got to treat them like they're real people. (Episode Six; emphasis added)

Taylor is throughout the season more frequently described as a 'bitch' than a 'fag'. Although the two terms are largely used interchangeably, it could be argued that the emphasis placed on the first highlights more clearly that Taylor's marginalisation, achieved through this labelling process, goes beyond his sexual orientation, resulting mainly from his perceived unmanliness, weakness and dishonesty. As is evident in the above scene, Kevin does not label Eric a 'bitch' for being gay but instead blames Taylor for outing him. A similar point is made by Eric himself in the same episode when asked by a journalist to send a message to his fellow gay athletes. 'I've got nothing to say to them. I'm gay, but I'm not a faggot,' he states abruptly, clearly regarding the expectation of him to act as a gay role model in the aftermath of the incident as posing a threat to his masculinity.

Furthermore, the 'bitch' discourse used to establish Taylor's 'otherness' suggests that male and female sexual violence ultimately have common grounds, originating from a prevalent patriarchal ideology and misogynist language which is as harmful for men as it is for women (Stanko, 1990; Hooks, 2000). In the first encounter between the basketball team's cocaptains outside the pitch, we see Eric showing Kevin a sexy photograph of a female classmate of theirs (Nikki) and saying 'Bitch looking good, huh? I so want to rape that' (Episode One; emphasis added). Whether literally or metaphorically interpreted, the use of the verb 'rape' in this way blurs the boundaries between legitimate and unacceptable sexual behaviour, ultimately trivialising the issue of rape. Similarly, in Episode Three, Eric's mother considers the use of such misogynist language by her son as an indicator that the rape allegations against him might be true. 'I heard him talking on the phone,' she says, concerned, to Eric's father. 'It was "bitch" this, "whore" that. I don't even know him anymore'. It could be argued that the shift of focus from female (e.g. Nikki) to male (e.g. Taylor) recipients of the 'bitch' label as 
the narrative progresses suggests that the risk of sexual violence posed by the use of this 'bitch' discourse is in both cases the same, essentially framing male and female sexual victimisation as part of the same problem.

Nevertheless, American Crime underlines the challenge of such an expansion of the domain of the well-established problem of 'female rape' towards male victims in patriarchal societies where 'real men' supposedly do not get raped (Cohen, 2014). The selection of the gender-neutral name 'Taylor' for the alleged victim is, most likely, far from random, as it allows the creators to draw viewers' attention to the differential perception of male and female rape. The following exchange from Episode Two (emphasis added) clearly shows that the police officer taking Anne Blaine's statement finds it difficult to believe the victim of the alleged sexual assault is male and not female:

\footnotetext{
Victim's name?

Taylor.

Where's she now?

Taylor's my son.

The victim's a male?

Yes, my son.

And this is a sexual assault?

Yes.
}

Likewise, Kevin LaCroix's mother, Terri, takes for granted that the alleged victim is female to the point that, when the family's lawyer informs her there were no traces of the rape drug GHB 'in his (meaning Taylor's) bloodstream' (Episode Three; emphasis added), she reacts in the following way:

'His'? Kevin's?

The person making the sexual assault claim is a boy...

[...] The boy's saying he was raped? But, no, that didn't happen. It didn't happen because boys don't get raped. First of all, boys don't do that to other boys. And even if he could...The boys fight back. Wait, are they even taking this seriously? 
The character, however, who most effectively pushes back against such male rape myths and describes what it feels like for male victims to have their traumatic experiences framed as part of what is predominantly considered to be a female problem (Javaid, 2016) is no other than Taylor Blaine himself. Talking to his therapist in Episode Three (emphasis added), he states:

\footnotetext{
Look, if I was a girl...People lose their minds when something happens to a girl. They have rights groups supporting them. They have lesbians out hating men, but...a guy?

You really believe people don't care when a male is violated?

I put a mattress on my back and carry it around, you think they're gonna put me on TV?

[...] You want that kind of attention?

I just want it to be over.
}

Blurring the boundaries between fact and fiction in this scene, Taylor clearly refers to the highly-publicised 'Mattress Performance (Carry That Weight)' art project (2014-2015), which involved a female Columbia University student symbolically shouldering the weight of her sexual violation. Emma Sulkowicz was carrying a 50-pound mattress around campus for several months until the day of her graduation to protest against the University's decision not to expel her alleged rapist (Sulkowicz's classmate, Paul Nungesser) (Bazelon, 2015). Taylor's implicit reference to Sulkowicz's case attests to the writers' intention to stress the thin boundaries between the fictional universe of American Crime and the physical world, while pointing to the limited newsworthiness and support available for male (as opposed to female) rape victims. Taylor's words suggest that any attempt to expand the domain of 'rape' to cover not only female but also male victimisation is very awkward as the two conditions appear to be competing with each other for the public's attention. From this perspective [which echoes Cohen's (2014) and Javaid's $(2015,2016)$ studies], instead of facilitating the construction of the 'male rape' problem, any attempt towards such a domain expansion ultimately overshadows male victims. Individuals like Taylor are thereby subjected to a prolonged ordeal which goes beyond their sexual violation and denies them their 'victim' status not just because they are not 
'real men' (who can allegedly not get raped), but because they are not real women either (who are considered the only legitimate victims of rape).

Finally, American Crime does not provide a straightforward answer on what actually happened between Taylor and Eric at the school party but explores the ambiguous nuances of sexual consent. 'Did you go there to have sex with him [Eric]?' Anne Blaine asks her son in Episode Four after finding out about the messages he had been exchanging with Eric prior to the party where the alleged rape took place. Taylor replies to her question by saying that 'he didn't go there to get attacked'. Despite the emphasis placed throughout the narrative on the emotional toll the alleged rape takes on Taylor, the writers do not demonise Eric; instead, they leave open the possibility that it is he who is the real victim of this unfortunate situation and not Taylor, allowing viewers to draw their own conclusions based on the claims presented by each side. When the police investigation brings to light the sex communication between him and Taylor, and his homosexual preferences become public knowledge, Eric sees his hegemonic masculinity as being put at risk and, unable to cope, attempts to take his own life. Most importantly, Eric claims the 'victim' status for himself, stressing the disproportionate burden of proof placed in cases of alleged rape on the accused rather than the accuser. Frustrated at the distrust and long-lasting stigma those who have been falsely accused of rape are faced with, he states:

He (Taylor) lied about me. But he gets to be the victim. I told the truth. But the rest of my life, they're gonna think I attacked him. [...] Somebody screams 'rape' and nobody cares what really happened. How does he get to own that night? How does he get to own me? (Episode Ten)

\section{Cycle of violence}

American Crime does not exclusively focus on Taylor's alleged victimisation at the basketball team's party. It also places the issue of male rape in a wider social context, exploring violent behaviours that have preceded or succeeded this particular incident. Within this cycle of 
violence, the roles of 'victim' and 'perpetrator' asserted by the characters taking part in the represented claims-making process are not mutually exclusive but might often overlap with each other. ${ }^{3}$ Following her son's suicide attempt, Eric's mother tells her husband that he 'should have taught him how to be a man', that 'it [homosexuality] doesn't go away, they don't get better'. She then asks Eric's father, 'Did you ever touch him? [...] They get it from somewhere' (Episode Six), as if homosexuality (and, by extension, her son's rape urges) are a contagious and incurable disease. The scene makes viewers aware of the possibility that Eric might have been sexually abused by his father, but most importantly raises questions over the impact his mother's homophobic views could have had on him. In that way, the writers draw attention to the alleged rapist's upbringing; they indicate that homophobic discourse is not exclusively found among adolescent males in a high school setting but also within the family, ultimately stressing the multifaceted links between homophobia and violence. The issue of homophobic upbringing is also considered in another scene of the same episode, where Taylor explains to Nate (a close friend of his mother who took care of him as a child while she was undergoing treatment for her depressive psychosis) why he stopped wanting to go to football games with him:

They [the Colts] were playing the Packers one time. They were getting killed. And you started screaming, 'Stop playing like queers! Quit playing like a bunch of queers!' loud as you could, over and over, right in front of my face. Same man who spent eight months raising me, screaming about queers.

The juxtaposition of the two scenes suggests that the alleged victim and perpetrator might not necessarily be very different from each other.

Moreover, Taylor's role not merely as a 'victim' but a 'victim-perpetrator' is also explored in the show. In Episode Six, Taylor receives a call from Eric who, pretending he wants to meet and discuss what happened at the party, sets him up to get beaten by his basketball teammates. When asked by the police why he helped with the planning of the attack, Eric 
confirms his 'perpetrator-victim' status by replying: 'They were looking to mess somebody up. It was either Taylor or it was me. As far as they cared, any fag will do' (Episode Ten). After the attack, however, Taylor - who has until then been largely constructed through this 'fag' discourse as weak and unable to control the situation he created with his accusations - refuses to play the role of the victim any longer and decides to fight back. He gets possession of a gun and attempts to take revenge on all those who hurt him, eventually killing the student who led the attack against him (Wes Baxter).

Furthermore, the writers' intention to explore male rape as part of a broader cycle of violence and establish it as not just a fictional but a serious real-life problem requiring immediate attention is most evident in Episode Eight. By adopting a documentary-like structure which weaves real-life interviews with parents and teachers affected by the Columbine high school shooting of 1999 as well as with other victims of LGBT bullying into the show's fictional narrative, American Crime acquires an additional layer of authenticity. As fact and fiction merge into one, the interaction between the show's entertainment and informative functions becomes clearer than ever.

\section{Institutional failure and vigilante justice}

Institutional failure is another key theme permeating the American Crime narrative which portrays the formal and informal responses to male rape allegations as being largely myopic, focussing almost exclusively on placing blame and thereby overlooking the victims' feelings and support needs. Taylor Blaine is let down by school officials treating his claims as a crisis to be managed and being more invested in minimising the impact of these claims on the school's good reputation than in helping him cope with his trauma. Moreover, Taylor is let down by the criminal justice system. The police officers in charge of the investigation are 
portrayed as being not just skeptical of the assertions made due to the gender of the alleged victim, but even reluctant to be involved in this case and uncertain about how to handle it. 'You really want to do this to your son? [...] Kids do dumb stuff,' one of the detectives tells Anne Blaine in Episode Two, dismissing the seriousness of the issue and suggesting that it would be preferable to resolve it through less formal avenues that do not require the police's intervention. For the most part of this scene, the camera is fixed on Anne Blaine's frustrated face, while the viewers get only a few glimpses of the police officer's mouth and hands taking notes. It could be argued that such camera work is indicative of the director's intention to juxtapose the emotional toll the situation takes on those involved with the cold, perfunctory treatment they receive from criminal justice agents. A similar technique is used in the same episode's sexual assault testing scene, where the camera focuses on Taylor's facial expression while the voice of a nurse talks him through the process in a friendly, yet almost robotic, manner. The closeups of Taylor's face, which aptly capture his nervousness and humiliation, are only briefly interspersed with shots-memories of him lying helpless on the floor in his underwear during the basketball team's party.

Going back to the aforementioned encounter between Anne Blaine and the police detective in Episode Two, there is an evident discrepancy between that scene and the last scene of Episode Three regarding the legal definition of rape. When Taylor's mother states in Episode Two that her son was raped, the detective replies: 'That's a specific category of crime. Forced intercourse with a member of the opposite sex.' This reply points once again to the double standards for male and female sexual victimisation and leaves Anne Blaine feeling powerless. 'What do you want to call it?' she asks twice. 'I don't care what you call it. I just need you to do something'. However, in the last scene of the following episode, the same detective informs principal Graham that they found semen on Taylor's clothes and are therefore 'officially looking at this [incident] as a rape' (emphasis added). If this discrepancy is intentional rather 
than an oversight on the writers' part, it could be regarded as showing that even police officials are unclear over how cases of male rape should be dealt with, which leaves those affected feeling like they are not being taken seriously. As Taylor confesses to his therapist in Episode Three:

I'm sorry I ever opened my mouth. I'm sorry I ever said anything about what happened to me. I got my mom dragging me around to the cops, to doctors. She's telling them I got assaulted, and... they're all just, like, smirking and cutting on me and...

Why do you think that?

I don't think it. They were doing it.

In addition, the writers place further emphasis on the marginalisation of male rape victims from the criminal justice process and their consequent disenchantment with the formal responses to their allegations through the use of a 'home being broken into' metaphor. In the slam poetry student competition scene that opens Episode Four, a male contestant says:

I don't remember what my rapist was wearing.

[..] I don't remember what time it was, how long it lasted, or how he held me.

I do remember that the word 'rape' never felt like it belonged to me in the first place.

Or after the responding officers rolled their eyes or after you asked me if I was sure that a man could be raped. I mean really raped.

I'm sure that I remember it feeling like every room of my home being broken into at the same time.

I'm sure that I had to start speaking in metaphor for you to start listening.

[...] Remember how I told you that it felt like every room of my home being broken into at the same time?

Remember how busy you were trying to figure out how they got in that you forgot all about the person living there?

In this exploration of the emotional toll of male rape, American Crime does not merely depict the victims' frustration with the inefficiency of the criminal justice system, but also underlines the risks deriving from it, namely from the attempts of disappointed victims to get justice through extra-legal avenues. As discussed in the previous section, Taylor turns from victim to perpetrator when he decides he cannot rely on the authorities to punish those who harmed him and resorts to vigilantism. He takes a gun and ends up killing Wes, thereby 
perpetuating the cycle of violence his own victimisation had started. Awaiting trial, Taylor is informed that it could help his defence if Eric told the jury that Wes had previously assaulted him. Taylor is therefore failed once again by the criminal justice system as he finds himself in a situation where he is expected to rely on Eric's, that is, his alleged rapist's favourable testimony to receive a more lenient sentence. To avoid this, he decides to plead guilty instead of going to trial. When his mother tries to change his mind, he tells her:

\footnotetext{
How do you think it makes me feel to have my future depend on the guy who raped me? He raped me, and he gets to be my savior? He gets to put on a suit and go into court and talk about how he's gonna do right? [...] Not putting this on a jury or my rapist $[\ldots]$, that feels good. (Episode Ten)
}

At the same time, the show raises important questions over the role of both traditional media and the Internet in pointing out malpractices and thereby providing justice for the victims in a way that the authorities fail to do. All the key players in the claims-making process triggered by the incident at the basketball team's party are fully aware and act knowing that Taylor's claims are not assessed strictly within the narrow confines of the criminal justice process, but also in the 'court of public opinion' (Episode Six; see also Greer and McLaughlin, 2011). Dissatisfied with the school's and the police's responses to her allegations about her son having been raped, Anne Blaine decides that the only way to have her voice heard is by contacting a journalist and going public with the story. At a later stage in the narrative, she also accepts the help offered to her by Sebastian, a cyber-activist who identifies himself as 'a white hat, hacking for justice' (Episode Nine). Seeing Anne and her son 'getting railroaded' and feeling a moral duty to intervene, Sebastian hacks into the school's servers; he then posts online all the incriminating evidence (e-mails, memos etc.) showing how the school board had mishandled Taylor's case.

However, this so-called 'trial by media' (Greer and McLaughlin, 2011) soon spins out of control, creating a volatile situation where Taylor and Anne Blaine hardly get the justice they yearn for, but instead see their emotions being as neglected as within the criminal justice 
process and the invasion of their privacy becoming collateral damage. As soon as Anne Blaine's medical records showing her history of depressive psychosis are leaked online, the news media's focus shifts from what happened to her son to whether there is any truth to her claims that he was raped. Likewise, Sebastian's plan to help Taylor Blaine also backfires when a rival hacker (Evans Webb) with a more extreme moral code starts going after the families of those involved by posting online damning private information about them, albeit not necessarily relevant to the basketball party incident.

From the posting of Taylor's photos on social media to the risks of online vigilantism, the show draws attention to the new challenges the rape victim is faced with in the digital era. The Internet is largely constructed as an unregulated medium where anything goes and nothing ever gets forgotten. The ubiquity of the medium makes it impossible for the victim to move on. Describing how upset he gets from seeing comments, likes and pictures of his attacker on his social media feed, Taylor says:

If I got dragged in an alley somewhere, I could just stop walking past that alley. But this ass...who did what he did [...] He's in my space. He's on my phone. Without even trying, he gets to do what he did to me again every day. (Episode Six)

In an attempt to take back control of his 'hijacked' project, Sebastian tracks down Evans and asks him to stop 'making it dirty', only to be told that '[n]obody controls the digital space' (Episode Ten). It is precisely this lack of accountability online that fails to protect vulnerable individuals like Taylor from further suffering.

\section{Discussion}

The analysis has shown that American Crime's portrayal of male sexual victimisation is largely counter-hegemonic as it pushes back against the dominant construction of rape as a female 
problem and challenges common myths originating from the all-encompassing heteronormative ideology (that men cannot get raped; that 'real' men fight back; that men who deviate from the established sexual norms deserve to be raped and so on; Javaid, 2015). The show does not consider the issue of male rape in a vacuum but looks at the wider social context within which such an incident occurs and is made sense of. In that way, it highlights the potential links between misogyny, homophobia and sexual victimisation; the cycle of violence victims and perpetrators find themselves trapped in and the frequent overlap between these roles; finally, the shortcomings of the criminal justice system which, by failing to effectively support the male rape victim, increases the risk of vigilante justice. By placing male rape at the centre of its narrative, American Crime adopts a victimological perspective which juxtaposes male and female sexual violence. It stresses that, although females are not the only victims of hegemonic masculinity (Stanko, 1990; Hooks, 2000), male victims often find themselves suffering in silence as they are more stigmatised than, and overshadowed by, their female counterparts (Cohen, 2014; Javaid, 2016).

Most importantly, American Crime does not shy away from stressing the complexity of its subject matter; it does not provide any straightforward answers, but instead encourages its viewers - interactional participants (Kress and van Leeuwen, 2006) to reflect on the nuances of such problematic situations and their real-life ramifications. By drawing parallels to real-life cases (like Emma Sulkowicz's 'Carry that Weight' project or the Columbine shooting), the show blurs the boundaries between fact and fiction, thereby not just entertaining viewers but being elevated into a form of 'edutainment' (Klein, 2011): it considers the nature, causes and appropriate responses to male rape, offering an insight into this rather neglected social issue and contributing to the relevant claims-making process. Commenting on the themes of the show, its creator, John Ridley, explains that he wishes to 'use [American Crime] as a catalyst' to raise awareness over male rape which, despite the 'staggering numbers' of people affected, 
is still an issue that does not receive the attention it deserves. 'I had no idea what was going on, what people were dealing with, how people weren't dealing with it [male rape] and the urgent need to discuss it,' he admits in the Inside American Crime Season 2 documentary.

Such a discussion on male sexual victimisation, let alone on the seriousness of the problem in educational settings, is nowadays more topical than ever. In recent years, there have been increasing concerns over the alarming levels of sexual violence among US and UK school, college and university students, which have led to the development of intervention programmes aimed at mobilising prosocial behaviour among bystanders (Napolitano, 2015; Fenton et al., 2016; Jeffreys, 2016; Franklin, Brady and Jurek, 2017). Simultaneously, the emergence of the \#MeToo movement in the aftermath of the Harvey Weinstein scandal in 2017 also brought to the fore issues of sexual harassment and abuse, with TIME magazine naming the 'silence breakers' Person of the Year 2017 (Zacharek, Dockterman and Sweetland Edwards, 2018). While these recent developments undoubtedly constitute positive steps towards exposing the hegemonic masculinity roots of sexual violence, it can be argued that, in the context of such intervention initiatives and the \#MeToo movement, the male victim still seems to be 'symbolically annihilated' (Tuchman, 1978) in favour of his female counterpart. Indicatively, while there are both male and female 'silence breakers' featuring in the above-mentioned TIME article, the former are fewer in numbers and none of them appears in that issue's (all-female) cover dedicated to \#MeToo. Feminists like Gillespie (1996) would probably claim that this disproportionate focus on female rather than male victims is dictated by the fact that women are much more frequent targets of sexual violence than men. However, such a claim not only echoes male rape myths (namely, that men are not that affected by rape), but also overlooks the 'dark figure' of male sexual victimisation which makes any comparisons to female victimisation very difficult. In any case, Cohen (2014) wisely observes that such attempts to 
compare and contrast male rape with female rape are counter-productive, leading to a further polarisation of the relevant debate and aggravating the harm caused to the victims.

From a constructionist perspective, there is a clear difference between being a 'silence breaker' and actually being heard; a difference aptly reflected in Taylor Blaine's plight in American Crime. In order for male victims to have their voices heard, it is vital that male rape be conceptualised as a problem in its own right instead of continuing to be framed in feminist terms. TV shows like American Crime (and popular culture in general) have the potential to contribute to the relevant social problem process by reaching out to a wide audience, raising awareness over male sexual victimisation and calling into question dominant perceptions of the issue. This is, of course, not an easy task, especially given the competitive nature of the contemporary popular TV landscape which, despite having become more 'socially aware' in recent years, still prioritises the production of unambiguous, easy-to-follow narratives seeking to appeal to as large an audience as possible (Henderson, 2007). As the creator of American Crime, John Ridley, notes in Inside American Crime Season 2, it is crucial that the producers of such 'socially aware' TV shows 'try to balance the creative needs of being on television with more urgent needs of speaking to realities that exist right now [...] around the world'.

Nevertheless, where the balance lies between informing audiences about alarming social issues and keeping them entertained is debatable. Consequently, there is always the risk of rape storylines being used on fictional TV merely as a narrative device to shock viewers and move the plot forward than to raise public awareness. At the time of writing (May 2018), the controversy sparked by a graphic male rape scene featuring in the second season of 13 Reasons Why attests to the thin line between 'edutainment' and the shock value of such fictional portrayals of sexual violence. Many viewers reportedly found the scene disturbing and gratuitously violent, while the US Parents Television Council urged the streaming provider Netflix to cancel the show (Henson, 2018). Responding to these criticisms, 13 Reasons Why's 
creator Brian Yorkey (quoted in Lockett, 2018) argued that openly discussing sexual victimisation was essential to its destigmatisation and that similar rape scenes in the first season of the show had not elicited the same backlash because the victims had been female:

\footnotetext{
When we talk about something being 'disgusting' or hard to watch, often that means we are attaching shame to the experience. We would rather not be confronted with it. [...] This is why these kinds of assaults are underreported. This is why victims have a hard time seeking help. We believe that talking about it is so much better than silence. [...] The fact that this [male rape scene in season 2] would be somehow more disgusting than what happened to Hannah and Jessica [female characters sexually assaulted in season 1], I'm shocked but not surprised.
}

Although Yorke employs a rather contentious strategy, his aim is not that different from John Ridley's, since they both regard their shows as a means to not just entertain viewers but inform them about male rape; a serious social problem which currently receives nowhere as much attention as female rape. In the pursuit of this goal, it is imperative that the issue of male sexual victimisation is handled with the utmost sensitivity. American Crime proves that an informed exploration of the relevant themes does not necessarily need to include the depiction of the actual rape incident, which (no matter how accurate it is) could potentially alienate viewers or cause further distress to those who may have been sexually victimised themselves. It is therefore suggested that TV shows adopting American Crime's rather than 13 Reasons Why's approach are much more suitable to trigger a constructive dialogue over male rape which could help consolidate the issue's 'problem' status, explore its intricacies and ultimately make a real difference in the lives of those affected by it.

\section{Concluding remarks}

This chapter has looked at the role of popular TV in the construction of 'male rape' as a social problem. Focusing on the second season of American Crime, the study has offered an in-depth analysis of the key themes of the show, including the blaming and stigmatisation of the male victim of sexual violence; their marginalisation as a result of the dominant feminist framing of 
sexual victimisation; and finally, the failure of the existing criminal justice system to effectively handle male rape cases, which not only lets victims down but may even lead to a perpetual cycle of violence in the form of vigilante justice. As a case study, this project has considered the portrayal of these issues in American Crime culturally significant in its own right: while acknowledging that its findings do not necessarily apply to all representations of male rape on fictional $\mathrm{TV}$, this research makes an important contribution to the study of a rather under-researched topic, that is, the media construction of male rape. It has been argued that the cultural significance of TV shows like American Crime consists in their ability to extend beyond their fictional universe and provide an in-depth exploration of real-life problems. In other words, they can serve as a form of 'edutainment' which has the power to raise awareness over male sexual victimisation and push back against dominant male rape myths. At the same time, such shows offer a better insight into the victims' experiences and potentially get audiences much more emotionally involved than pertinent factual sources of information.

The present study is, of course, not without limitations, the first one being its limited focus. A future comparison between the portrayal of male rape in American Crime and other TV shows or films could offer a more comprehensive analysis of the issue, while the inclusion of non-American texts would allow for an in-depth understanding of the popular cultural framing of male rape across different countries. Last but not least, while the qualitative analysis of media content in itself enables the researcher to assess (as in this case) the extent to which the text under study reproduces dominant ideologies, it does not allow any conclusions to be drawn about the ways in which this particular content is actually interpreted and experienced by audiences. It is vital that the argument made here about the appeal of 'socially aware' fictional narratives and their role in raising awareness over male sexual victimisation be empirically tested. Additional research on media consumption would complement the present 
study by evaluating the influence of American Crime and other popular cultural products on viewers' perceptions of the problem of male rape.

\section{References}

Abdullah-Khan, N., 2008. Male Rape: The Emergence of a Social and Legal Issue.

Basingstoke: Palgrave Macmillan.

Altheide, D. and Schneider, C., 2013. Qualitative Media Analysis. 2nd ed. London: Sage.

American Crime, 2016. Inside American Crime Season 2, ABC [video online] Available at: $<$ https://abc.go.com/shows/american-crime/video/behind-the-scenes-american-crimeseason-2> [Accessed 28 May 2018].

American Crime, 2016. Season Two Episodes, ABC [video online] Available at: <http://abc.go.com/shows/american-crime/episodes/season-02> [Accessed 06 May 2016].

Baudrillard, J., 2001. Simulacra and Simulations. In M. Poster, ed. Jean Baudrillard: Selected Writings. $2^{\text {nd }}$ ed. Cambridge: Polity. pp. 169-187.

Bazelon, E., 2015. Have We Learned Anything from the Columbia Rape Case? The New York Times Magazine, [online] 29 May. Available at <https://www.nytimes.com/2015/05/29/magazine/have-we-learned-anything-from-thecolumbia-rape-case.html> [Accessed 17 May 2018].

Bednarek, M., 2010. The Language of Fictional Television. London: Continuum.

Best, J., 1990. Threatened Children: Rhetoric and Concern about Child-Victims. Chicago: University of Chicago Press.

Best, J., 2008. Social Problems. New York: W. W. Norton. 
Birnbaum, D. and Holloway, D., 2017. Pushing Buttons / Broadcast Gets Woke. Variety, 14 Mar. pp. 1, 34-38.

Blumer, H., 1971. Social Problems as a Collective Behaviour. Social Problems, 18(3), pp. 298-306.

Burr, V., 2015. Social Constructionism. 3rd ed. London: Routledge.

Butler, J., 2004. Undoing Gender. London: Routledge.

Butler, J., 1993. Bodies That Matter. New York: Routledge.

Cohen, C., 2014. Male Rape is a Feminist Issue. Basingstoke: Palgrave Macmillan.

Creswell, J.W., 2007. Qualitative Inquiry and Research Design. $3^{\text {rd }}$ ed. Thousand Oaks: Sage.

deMoraes, L., Full 2015-16 TV Season Series Rankings. Deadline Hollywood, [online] 26 May. Available at: <http://deadline.com/2016/05/tv-season-2015-2016-series-rankingsshows-full-list-1201763189/> [Accessed 03 May 2018].

Donnelly, D. and Kenyon, S., 1996. Honey we don't do men: Gender stereotypes and the provision of services to sexually assaulted males. Journal of Interpersonal Violence, 11(3), pp. 441-448.

European Institute for Gender Equality, 2016. Analysis of National Definitions of Rape. [online] Available at:

<http://eige.europa.eu/sites/default/files/documents/database/gbv_natdefn_rape.pdf> [Accessed 03 May 2018].

Fenton, R., Mott, H. McCartan, K. and Rumney, P., 2016. A Review of Evidence for Bystander Intervention to Prevent Sexual and Domestic Violence in Universities. London: Public Health England. Available at: 
<http://socialsciences.exeter.ac.uk/media/universityofexeter/collegeofsocialsciencesandint ernationalstudies/research/interventioninitiative/resources/PHE_PublishedLitReviewApr2 016.pdf> [Accessed 04 May 2018].

Ferrell, J., 1999. Cultural Criminology. Annual Review of Sociology, 25(1), pp. 395-418.

Franklin, C., Brady, P. and Jurek, A., 2017. Responding to Gendered Violence Among College Students. Journal of School Violence, 16(2), pp. 189-206.

Gillespie, T., 1996. Rape Crisis Centres and Male Rape: A Face of the Backlash. In: M. Hester, L. Kelly and J. Radford, eds. Women Violence and Male Power. Buckingham: Open University Press. pp. 148-165.

Graham, R., 2006. Male Rape and the Careful Construction of the Male Victim. Social \& Legal Studies, 15(2), pp. 187-208.

Gramsci, A., 1968. Prison Notebooks. London: Lawrence \& Wishart.

Greer, C. and McLaughlin, E., 2011. 'Trial by Media': Policing, the 24-7 News Mediasphere, and the 'Politics of Outrage'. Theoretical Criminology, 15(1), pp. 23-46.

Henderson, L., 2007. Social Issues in Television Fiction. Edinburgh: Edinburgh University Press.

Henson, M., 2018. Urgent Warning to Parents and Schools about Netflix's '13 Reasons Why' Season Two. Parents Television Council blog, [blog] 21 May. Available at: <http://w2.parentstv.org/blog/index.php/2018/05/21/urgent-warning-to-parents-andschools-about-netflixs-13-reasons-why-season-two> [Accessed 26 May 2018].

Hooks, B., 2000. Feminism is for Everybody: Passionate Politics. Cambridge, MA: South End Press. 
Javaid, A., 2015. Male Rape Myths: Understanding and Explaining Social Attitudes Surrounding Male Rape. Masculinities and Social Change, 4(3), pp. 270-294.

Javaid, A., 2016. Feminism, Masculinity and Male Rape: Bringing Male Rape 'Out of the Closet. Journal of Gender Studies, 25(3), pp. 283-293.

Javaid, A., 2017. Can’t Hear or Won't Hear: Gender, Sexualities and Reporting Male Rape. InterAlia: A Journal of Queer Studies, [online] Available at: <http://www.interalia.org.pl/en/artykuly/on_a_rolling_basis/cant_hear_or_wont_hear_gen der_sexualities_and_reporting_male_rape.htm> [Accessed 03 May 2018].

Jenkins, P., 1994. Using Murder: The Social Construction of Serial Homicide. New York: Aldine de Gruyter.

Jennings, W., Piquero, A. and Reingle, J., 2012. On the Overlap between Victimization and Offending. Aggression and Violent Behavior, 17(1), pp. 16-26.

Kress, G. and van Leeuwen, T., 2006. Reading Images: The Grammar of Visual Design. $2^{\text {nd }}$ ed. London: Routledge.

Kitzinger, J., 1999. A Sociology of Media Power: Key Issues in Audience Reception Research. In: G. Philo, ed. Message Received. Harlow: Addison Wesley and Longman. pp. $3-20$.

Klein, B., 2011. Entertaining Ideas: Social Issues in Entertainment Television. Media, Culture \& Society, 33(6), pp. 905-921.

Kubey, R. and Csikszentmihalyi, M., 1990. Television and the Quality of Life. London: Routledge. 
Lockett, D. 2018. '13 Reasons Why’ Creator Defends Controversial Rape Scene. Vulture, [online] 22 May. Available at: < http://www.vulture.com/2018/05/13-reasons-why-season2-finale-rape-scene.html> [Accessed 26 May 2018].

Loseke, D., 2003. Thinking about Social Problems. $2^{\text {nd }}$ ed. New Brunswick: Aldine Transaction.

Lowry, B., 2016. TV Review: ‘American Crime’ Season 2. Variety, [online] 4 January. Available at: <http://variety.com/2016/tv/reviews/american-crime-season-2-reviewfelicity-huffman-regina-king-timothy-hutton-john-ridley-abc-1201668921/> [Accessed 04 May 2018].

Ludwig, G., 2011. From the 'Heterosexual Matrix' to a 'Heteronormative Hegemony'. In: M. Castro Varela, N. Dhawan and A. Engel, eds. Hegemony and Heteronormativity. Farnham: Ashgate. pp. 43-61.

Manning, P., 1998. Media Loops. In: F. Bailey and D. Hale, eds. Popular Culture, Crime and Justice. Belmont: Wadsworth. pp. 25-39.

Maratea, R.J. and Monahan, B., 2016. Social Problems in Popular Culture. Bristol: Polity Press.

Mason, P. 2006. Prison Decayed: Cinematic Penal Discourse and Populism 1995-2005. Social Semiotics, 16(4), pp. 607-626.

Miller, R., 2017. Dramas like Broadchurch have helped rape survivors speak out. But services need funds. The Guardian, [online] 27 February. Available at: <https://www.theguardian.com/commentisfree/2017/feb/27/rape-crisis-funding-sexualviolence-rise> [Accessed 30 April 2018]. 
Mitchell, D., 2005. Producing Containment: The Rhetorical Construction of Difference in 'Will \& Grace'. The Journal of Popular Culture, 38(6), pp. 1050-1068.

Mopas, M., 2007. Examining the 'CSI effect' through the ANT lens. Crime, Media, Culture, 3(1), pp. 110-117.

Nagouse, E., 2018. ‘To Ransom a Man's Soul': Male Rape and Gender Identity in Outlander and 'The Suffering Man' of Lamentations 3. In: C. Blyth, E. Colgan and K. Edwards, eds. Rape Culture, Gender Violence and Religion. Basingstoke: Palgrave Macmillan. pp. 143158.

Napolitano, J. 2015. 'Only Yes Means Yes’: An Essay on University Policies Regarding Sexual Violence and Sexual Assault. Yale Law \& Policy Review, 33(2), pp. 387-402.

NBC News, 2012. Biden breaks down stance on same-sex marriage, Meet the Press. National Broadcasting Company (NBC) [video online], 06 May. Available at: <http://www.nbcnews.com/video/meet-the-press/47312632> [Accessed 30 April 2018].

Pascoe, C., 2011. "Guys are just homophobic": Rethinking Adolescent Homophobia and Heterosexuality. In: S. Seidman, N. Fischer and C. Meeks, eds. Introducing the New Sexuality Studies. $2^{\text {nd }}$ ed. Abingdon: Routledge. pp. 175-182.

Pitfield, C., 2013. Male survivors of sexual assault: To tell or not to tell? DClinPsych. University of East London. Available at: <http://roar.uel.ac.uk/3442/1/2013_DClinPsych_Pitfield.pdf> [Accessed 03 May 2018].

Ratner, P., Johnson, J., Shoveller, J., Chan, K., Martindale, S., Schilder, A. and Hogg, R., 2003. Non-consensual sex experienced by men who have sex with men: Prevalence and association with mental health. Patient Education and Counseling, 49(1), pp. 67-74. 
Rumney, P., 2009. Gay Male Rape Victims: Law Enforcement, Social Attitudes and Barriers to Recognition, The International Journal of Human Rights, 13(2-3), pp. 233-250.

Tithecott, R., 1997. Of Men and Monsters: Jeffrey Dahmer and the Construction of the Serial Killer. Wisconsin: University of Wisconsin Press.

Tuchman, G., 1978. The Symbolic Annihilation of women by the mass media. In: G.

Tuchman, A. Daniels and J. Benet, eds. Hearth and Home: Images of Women in Mass Media. New York: Oxford University Press. pp. 3-38.

Schlesinger, P., Murdock, G. and Elliot, P., 1983. Televising Terrorism, London: Comedia. Spector, M. and Kitsuse, J., 1987. Constructing Social Problems. Abingdon: Routledge. Stanko, E., 1990. Everyday Violence: How Women and Men Experience Sexual and Physical Danger. London: Harper Collins.

US Department of Justice., 2012. An Updated Definition of Rape. Office of Public Affairs, [online] 06 January. Available at: <https://www.justice.gov/archives/opa/blog/updateddefinition-rape> [Accessed 03 May 2018].

Walters, S., 2001. All the Rage: The Story of Gay Visibility in America. Chicago: The University of Chicago Press.

Williams, R., 1977. Marxism and Literature. New York: Oxford University Press. Zacharek, S., Dockterman, E. and Sweetland Edwards, H. 2018. TIME Person of the Year 2017: The Silence Breakers. TIME, [online] 14 April. Available at: < http://time.com/timeperson-of-the-year-2017-silence-breakers> [Accessed 04 May 2018].

\footnotetext{
${ }^{1}$ The use of the Gramscian concept of 'hegemony' (Gramsci, 1968) here seeks to stress that dominant ideologies (including that of heteronormativity, which favours a view of heterosexuality as the norm) are not necessarily enforced on people but are naturalised (often through popular culture), coming to be regarded as 'common sense'.
} 


\footnotetext{
${ }^{2}$ See http://abc.go.com/shows/american-crime/episodes/season-02.

${ }^{3}$ For a comprehensive review of the academic research on this victim-perpetrator overlap, see Jennings, Piquero and Reingle (2012).
} 